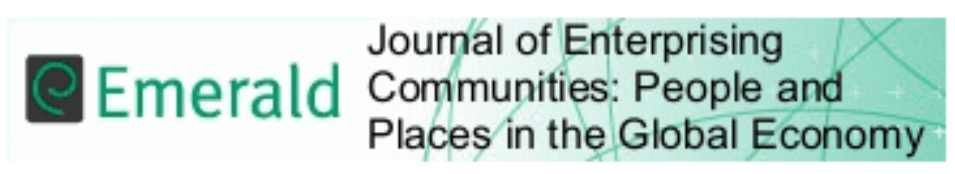

\title{
Beyond Words and Rhetoric - Small Voluntary Organisations and Effective Refugee Integration in the Communities
}

\begin{tabular}{|r|l|}
\hline Journal: & $\begin{array}{l}\text { Journal of Enterprising Communities: People and Places in the Global } \\
\text { Economy }\end{array}$ \\
\hline Manuscript ID & JEC-11-2018-0084.R1 \\
\hline Manuscript Type: & Academic Papers \\
\hline Keywords: & $\begin{array}{l}\text { Refugee Integration, Voluntary Organisations, Social Integration, } \\
\text { Inclusive Entrepreneurship, Inclusive Communities }\end{array}$ \\
\hline \multicolumn{2}{|l}{} \\
\hline
\end{tabular}

\section{SCHOLARONE \\ Manuscripts}




\title{
Beyond Words and Rhetoric - Small Voluntary Organisations and Effective Refugee Integration in the Communities.
}

\begin{abstract}
Purpose: Integration is a complex, contested and multidimensional concept. This paper examines the impact of small voluntary agencies (SVA) in the integration of refugees into social, economic and citizenship structures in the United Kingdom (UK).
\end{abstract}

Design/methodology/approach: This study is rooted in in-depth interviews with 20 participants and a case study (ethnography research) that focuses on a refugee-assisting organisation in Southeast England.

Findings: Our findings reveal cases of exemplary leadership in actions and social solidarity exhibited by SVA through innovative actions aimed at helping individuals and communities which may be particularly disadvantaged. It revealed the mixed embeddedness that these agencies create that enable refugees to pursue a new life, employment and citizenship.

Research limitations/implications: One of the limitations of the study is the focus on one case study. However, this provided an opportunity to conduct in-depth interviews and examination of the research objectives.

Practical Implications: With the ever-decreasing government revenues, there is evidence of the tremendous achievement of the voluntary sector (VS) in many endeavours in the community. This provides an opportunity for a more strategic partnership between public and private actors.

Social Implication: The activities of the SVA are the catalyst to refugees' integration as policies that enable regaining self-esteem, seeking employment or starting a business.

Originality/value: This study provides the opportunity to explore the relatively under-research and under-publicized role of SVA in the migrants and refugee literature.

Keywords: Refugee Integration; Voluntary Organisations; Social Integration; Inclusive Entrepreneurship and Inclusive Communities.

\section{Introduction}

If the agenda of the Organisation for Economic Co-operation and Development (OECD) of ensuring that all people, regardless of their personal characteristics and background, have an equal opportunity to start and run their own businesses (inclusive entrepreneurship) is to be achieved, the contributions of voluntary sectors will be critical 


\section{towards its attainment.}

This article examines the impact of small voluntary agencies (SVA) on the integration of refugees in the UK. The system of economic support which is in place for those going through the asylum system should, in theory, mean that Refugee Third Sector Organisations (RTSOs) are only supporting refused asylum seekers who are destitute (Mayblin \& James, 2017). Therefore, voluntary agencies play crucial social and economic roles by helping individuals and communities that may be particularly disadvantaged. Both refugees and asylum-seekers fall into this category. Several studies show that asylum seekers face many challenges such as language, discrimination, lack of skills, cultural shock, etc. (Lundborg \& Skedinger, 2016; van Heelsum, 2017; Valenta \& Thorshaug, 2012). In the UK, the majority of asylum seekers are not permitted to enter the labour market (Mayblin \& James, 2018). From inclusive entrepreneurship perspective (OECD, 2016 \& 2017), starting a business is not also easy for refugees.

The policy of integration of refugees is an important agenda in terms of labour market integration, education, housing, healthcare and cultural orientations (Scholten et al., 2017). Many previous studies (e.g. Griffiths et al., 2005; Spencer, 2006; Atfield et al., 2007; Phillips, 2006; Strang \& Ager, 2010; Trygstad, 2016; Konle-Seidl \& Bolits, 2016) have recognised that the integration of refugees is rarely a straightforward process. Evidence from the Scottish Refugee Council's Holistic Refugee Integration Service proposes that whilst integration depends on building social connections, new refugees can be very isolated, lacking in close relationships and with poor knowledge of services or how to access them (Scottish Government, 2017). The UK government defines refugee integration as:

"The process that takes place when refugees are empowered to achieve their full potential as members of British society, to contribute to the community, access public services and to become fully able to exercise the rights and responsibilities that they share with other residents in the UK" (Home Office, 2006 :3).

The settlement process is daunting and excruciating (Craig, 2015). Evidence from 10 European countries shows that one thing stands out firmly: all refugee integration strategies put highest priority on socio-economic integration, and then in particular labour market integration (Scholten et al., 2017). This prioritization of labour market integration is confirmed by another recent research project on refugee integration (Eurofound, 2016). Refugees are six times more likely to be unemployed than the rest of the population (Dhudwar, 2004). Therefore, in many cases, starting a business becomes the only realistic options for gaining personal income. This 
account for why immigrants have own shops in many urban and cities in Europe (Kloosterman, 2010). However, institutional and cultural barriers prevent refugees and migrants (especially youths) from finding jobs or starting a business (Lundborg \& Skedinger, 2016).

The institutional theory explains the role of the government in creating conducive economic and social environment (Dahles, Verduyn \& Wakkee, 2010; Igwe, Madichie and Newbery, 2018; Ratten \& Dana, 2017). Institutional thickness is generated by the embeddedness of businesses in personal relationships, high levels of social interaction with business partners, professional associations and government institutions (Dahles, Verduyn \& Wakkee, 2010). The integration of migrants and refugees is not only a government concern, non-governmental organisations, civil society bodies and of the business sector play an important role.

Although there is a growing sense of awareness of the need for refugee integration, there has been only little research to evaluate the strategies of the actors (Scholten et al., 2017). Also, much is known about the scope of the third sector response (such as the types of services being provided), but little is known about the scale (Mayblin \& James, 2017: 7). Our study makes important contributions given that there is a paucity of literature and research. As noted by Mayblin \& James, 2018), the Voluntary Refugee Organisations (VROs) within and beyond the UK has been under-researched and under-theorised within academia in recent years.

This study is rooted in a case study (ethnography research) that focuses on a refugeeassisting organisation in Southeast England. Through our case study organisation, referred to as 'The Focus Organisation' (TFO) throughout the paper to provide anonymity, this paper raises questions about nature of VROs actions, the resilience of small VROs, social solidarity and refugee lives. Refugees and immigrant entrepreneurship have emerged as an important field of study (Munkejord, 2017; Jacobsen \& Fratzke, 2016). It is important to note that in recent years, migrant entrepreneurship have been widely discussed (Knight, 2015; Stephens, 2013; Evans, 2012; Kyoung-Ho, 2014; Turkina and Thai, 2013; Crockett, 2013). However, we still know little about refugees' integration in the community and business society.

Within this context, our study examines the role that the VROs play in refugee integration and how this could be characterised for the benefit of wider and more effective strategies for migrant integration and the development of citizenship behaviour (See, e.g. Rafique \& Khoo, 2018; Konle-Seidl \& Bolits, 2016). Thus, the central question of our research is: 'What is the significance of the roles played by the VROs as they resolve integration issues created by the increasing numbers of migrants?' Doing so helps unravel the nature and form of leadership needed in the sector and thereby identify the necessary help for organisations (Bull, 2008; Ógáin, Lumley \& Pritchard, 2012). We argue that the practical assistance given to 
refugees bears direct consequences on refugee integration and inclusiveness. This concept is important in migration research as effective integration system is necessary if refugees are to exploit entrepreneurial opportunities in the wider business economy.

\section{Key Concepts and the Context of Refugees Integration and Voluntary sector}

The term refugee, in its social science meaning, refers to someone forced out of their country of habitual residence to seek protection in another sphere. This definition goes beyond the political connotation and captures the diversity of displaced people (Ruiz \& Vargas-Silva (2017). Much of the theoretical understandings implied in migrant and refugee integration have been integrated into the mixed embeddedness approach (developed by Kloosterman and Rath, 2001 and Kloosterman, 2010). Within this approach, opportunity structure is a central concept (Munkejord, 2017). Integrating refugees into labor markets (Scholten et al. 2017; Bevelander, 2016; Bevelander \& Pendakur, 2014; Konle-Seidl and Bolits, 2016) become an important element of embeddedness.

\subsection{Mix Embeddedness of Migrant and Refugees}

The literature on the social embeddedness shows how immigrants, in many cases lacking in financial capital, are nevertheless capable of starting a business by relying on their social capital Kloosterman, (2010). The integration of refugees is important for various reasons (Ruiz \& Vargas-Silva, 2018; Hack-Polay, 2008; Bloch, 2004). In his study of 'Migration and integration: A local and experiential perspective, Craig (2015) noted that whereas most discourse implies that integration is a good thing and is supported both by host country nationals (with the exception of the xenophobic right) and by most migrants themselves (again with exceptions who wish to remain enclosed within their own 'community'), there remain, particularly amongst new migrants, some who have at best a sense of ambivalence about the process of integration and many who do not see their migration as generating a long-term status. This assertion is also supported by another study by Vathi and King (2013).

Kloosterman, (2010) developed a framework for analysing (migrant) entrepreneurship from a mixed embeddedness perspective in which they assert that the wider societal context had to be invoked as certain groups of immigrants were pushed towards self-employment due to specific obstacles (i.e. discrimination) on the labour market. Indeed, there are groups for whom the notion of integration is particularly problematic: for example, people trafficked for the purposes of sexual or labour exploitation and other victims of criminal activity Craig (2015). 
These people are often deeply traumatised by their experience.

\subsection{Perspectives on the Voluntary Sector}

We are living in times of unprecedented displacement driven by conflict and persecution (Scottish Government, 2017). The number of migrants seeking asylum in the European Union (EU) has skyrocketed, from around 200,000 in 2006 to around 1.3 million in both 2015 and 2016 as revealed by Eurostat (2018). In the light of this development, more research needs to unveil the role that the voluntary sector (Konle-Seidl, 2018; Bull, 2008; Moskovich, 2015). Studies that have underscored the need for the VS sector to play the role of strategic partner and actor (see, e.g. Rutter, 2003) tend to take the view that state intervention can be patchy and ineffective since they may be hindered by politics (European Migration Network, 2016; Jacobsen \& Fratzke, 2016). Interestingly such studies expose the expertise that lies in the VS and the cost-efficiency that they could foster.

The leadership literature, in general, contends that effective leaders articulate a high need for power, a low need for affiliation and high activity inhibition (Steinmann et al., 2015). The conflict leadership model is administrative leadership in the term that Uhl-Bien et al. (2007) describe, i.e. top-down, hierarchical and focused on conflicting constraints and the use of authority. However, the leadership traits identified by Dearlove \& Clutterbuck (1996) point to the fact that the voluntary sector leadership diverges from leadership in the commercial or private sector and therefore deviate from the traditional models. Miller et al. (2012) argue that it is compassion, which complements traditional self-oriented motivations that drive social entrepreneurship of the voluntary sector. However, these scholars stopped short of associating compassion with leadership. The criteria for effective leadership identified for the voluntary sector exemplify the consensus or collaboration model of leadership (De Hoogh et al., 2010; Hack-Polay, 2007). Igwe, Icha-Ituma \& Madichie (2018) proposes that entrepreneurial leaders help address social issues by displaying innovation and openness to new opportunities.

Bowen, Newenham-Kahindi \& Herremans (2010:297) present an argument that idealises the role played by firms, which draws tremendous benefit from community engagement strategies. The authors reviewed over 200 academic and practitioner research papers and concluded that voluntary sector community engagement strategy can actually inform firms to develop corporate social responsibility (CSR) frameworks (Igwe, Icha-Ituma \& Madichie, 2018). Given the prominence of CSR initiatives, the authors propound that this could help businesses use it for competitive advantage. Whether this materializes in practice is a different debate because the issue of compassionate action still remains under-explored and under- 
developed especially within the voluntary sector's role in the refugee crisis.

The voluntary sector plays a momentous role in getting refugees to acclimatize to the new society and attain citizenship (Hack-Polay, 2016). The activity of "helping immigrants to make the necessary adjustments for life in host societies" (Shield, Drolet \& Valenzuela, 2016:4) has been argued. Sometimes in their fight to provide help, British voluntary organisations have become an extension to government services at critical times e.g. during the Bosnian conflict, the Kosovo crisis in the 1990s and mid-2000s (Rutter, 2003). For instance, the UK government relied extensively on refugee agencies to resettle refugees outside London and provide accommodation and welfare services after the 1999 Asylum and Immigration Act (Rutter, 2003). Alongside the work of larger immigrant assisting organisations, small community-based voluntary groups bring invaluable support for migrants to turn around painful memories of separation and flight (Sardinha, 2009). Despite these efforts, more sustained work in the area is needed to understand the fundamental factors behind such resurgence and positive theoretical developments.

Voluntary sector contribution, either independently or in support of state interventions, denotes a momentous expertise that the wider societal network could draw from (Rafique \& Khoo, 2018). We, therefore, posit that voluntary sector leadership offers other sectors learning that could contribute to building a more humane and compassionate society. As Katz \& Page (2010:59) contend "market economy predictably under-produces certain urgent public or collective goods [such as a clean environment] and perpetuates gross inequalities in resources among people and across regions”. However, social enterprise is preoccupied with mending broken communities.

\subsection{Social Solidarity, Voluntary Organisations and Refugee Integration}

Refugee integration initiatives and funding have suffered significant cuts in the UK in the past decade (Doyle, 2014). With public sector resources coming under pressure in the health sector, education, policing, etc., refugee work is relegated to the back of government priorities in terms of social policy and welfare provision. This has two main implications: (1) for voluntary organisations - (with the compassion to continue refugee assistance), there is a greater reliance on volunteers and cutbacks on services; (2) for refugees - that signifies more hardship which materialises in accrued homelessness, lack of training, employment opportunities, increased poverty and social isolation. Ruiz \& Vargas-Silva (2017) contend that refugees will benefit from improvement in services which become cornerstones for successful integration. The cuts in refugee resettlement services mean that over 117,000 refugees in Britain (Refugee Action, 2015) 
are risk becoming isolated in refugee enclaves which could represent barriers to inclusion.

Voluntary sector action is therefore closely associated with social solidarity. Molm, Collett \& Schaefer (2007) decry the receding research on social solidarity despite much research evidence that generalized (indirect) exchange produces greater social solidarity. The work of the voluntary sector, in many respects, exemplifies such indirect exchange through which our society provides assistance to refugees and vulnerable people who in turn, healed from social and psychological issues, can deploy themselves to help others (both individuals and society at large) (Atkinson et al. 2012).

\subsection{Compassionate Sector}

It is well-documented that such help appears to be patchy despite refugees' cries for practical assistance. Few studies have identified the current situation as bordering on a crisis whilst others have highlighted its abject negation by researchers (Bloch, 2004). Those organisations and schemes that have chosen to concentrate on the issues have encountered the lack of financial and human resources to carry out the necessary work. Amidst challenges, some voluntary organisations have striven to operate services that provide shelter, food, safety and a sense of belonging to a community. In other terms, voluntary organisations exemplify a culture of doing more with less as they help refugees to rebuild new lives. Such characteristics of benevolence and humane devotion displayed in the literature by the coming together of different individuals is what is termed in this paper as compassionate action.

Compassionate action has distinct characteristics which are about "engaging with each other as human beings, not just as human doings, Compassionate action elevates the consciousness of leaders and serves the highest good - not just employees and shareholders, but of the communities in which they operate" (Warrell (2017). Compassionate action is viewed as 'leading from head and heart' (ibid: 1), a requisite leadership model in refugee-assisting voluntary organisations (Page, 1998). Although Page made such observations two decades ago, the nature of social solidarity as encapsulated in the voluntary sector has been under-studied particularly within the context of the global refugee and humanitarian crisis. If compassionate action is situated in the context of social solidarity, then the study of refugee integration cannot be divorced from voluntary sector action. Nickel \& Eikenberry (2009) was critical of the fact that commercialization and consumerism have defrauded communities of many public spaces which have become shopping malls thereby robbing communities of the capability and space to provide much needed community-based services for social cohesion and integration issues in addressing mass migration crisis. 


\section{Methodology}

A qualitative and interpretative approach was adopted for our study (McKeever et al., 2015; Munkejord, 2017) rooted in ethnography research. As noted by Mayblin \& James (2018) research in this area takes a qualitative 'deep dive' case study approach in particular locales, or with particular large organisations, and focuses primarily on qualitative research interviews with small sample sizes. Over the last 20 years, multiple categorizations and ethnographic genres have emerged in the social science literature (Reeves, Peller, Goldman \& Kitto, 2013). Sometimes, it is also referred to as 'case study'. There are enormous advantages in treating ethnography as a distinctive type of research (Watson, 2012). It is based on a case study and an in-depth and holistic empirical description, based on the positivist notion. Collecting such histories are a "particular form of ethnography" (Galbraith, 2010: 310).

The research employed interviews with 20 participants in a charitable refugee-assisting voluntary organisation in southeast England. Participants were chosen through purposeful sampling procedure (Igwe, Newbery, Nihar, White and Madichie, 2018; Okolie, Igwe and Elom, 2018) aimed at selecting key members of the staff who had many years of working experience in the case study agency. Founded in the late 1990s, the group has grown from a small group of volunteers into a charitable organisation run by over 40 staff, including non-paid volunteers. It is a key agency in the county helping refugees to rebuild their education, training and professional experience and socio-psychological life.

It provides various services including welfare advice, training and befriending to help relieve the psychological trauma and other negative impacts of being in exile. The organisation has 10 paid staff and 35 volunteers. The choice of the small charity was guided by the intention to assess the impact of such groups in dealing with sensitive and emotive issues such as migration and integration into host countries despite having limited resources. We sought to establish how voluntary sector action achieves life-changing results for refugees. Participants included the CEO, 3 paid staff, 3 volunteers (who are refugees themselves) and 13 users. The opinions of the local MP were sought as an outsider to The Focus Organisation (TFO) but involved in social policy formulation.

The Chief Executive Officer (CEO) and paid staff were interviewed to draw information regarding strategy, leadership style and its impact on service delivery, the lives of the incoming migrants and organisational effectiveness. The volunteers were interviewed because they were regarded as an integral part of the staffing with knowledge of organisational values, culture and practices. The inclusion of clients in the sample was geared at assessing the impact of voluntary 
sector services on the lives of the refugee clients. Two interview schedules were used: one for both CEO and staff and the other for clients. The leader and staff interviews lasted approximately 45 minutes for each participant. The average time for clients was one hour and ten minutes. This difference in time was interesting as the researchers felt that beyond being appreciative of the service provided by TFO, the clients used the interviews as a platform for more social interactions with people other than fellow refugees. Also, we facilitated group interviews (Focus groups) that enabled the verification of responses from individual interviews and the possible omission of important issues (see e.g. Igwe, Madichie and Newbery, 2018).

The analysis followed a process of coding and categorization into emergent themes (see, e.g. Igwe et al., 2018). Given that the interview questions were structured around themes, the researcher initially coded items that supported the determined interview themes. Open coding enables researchers to familiarise themselves with each case as a stand-alone entity and allows unique patterns to emerge before attempting to identify cross-case patterns (García \& Welter, 2011). During the coding process, we formalised and added new themes by grouping codes that did not fit the initial interview themes. For reasons of confidentiality and anonymity, participants were coded: Chief Executive (CEO), Paid volunteers (Participants A, B, C), Unpaid volunteers (Participants D, E, F), Clients (Clients 1-13). The results are captured in the next section.

\section{Findings and Analysis}

Overall, our finding reveals the actions of the voluntary sector that complement government role in refugees' integration and inclusiveness. Therefore, VROs are the catalyst to refugees rebuilding their lives, settlement, seeking employment or starting their own business (inclusive entrepreneurship).

\subsection{Characteristics of voluntary sector action}

The data suggest that the attributes of voluntary sector action display some singularities that set it aside from other forms of provision by other sectors such as the private and public sectors in line with previous studies (Fitzpatrick et al., 2015; Price 2016; Phillimore and Goodson 2010; Mayblin \& James, 2018).

\subsubsection{Nature of voluntary sector action}

Voluntary organisations work with people with the compassion that fit the sector's business strategy and purpose. Leadership is practice with limited reliance on authority and power. However, there is a strong sense of involvement and trust. Managers, paid staff and volunteers 
agreed that all staff are an integral part of the team, thus, part of the decision-making process which is an attractive aspect of working in the voluntary sector. The unpaid volunteers emphasized this humane aspect in eloquent terms:

"In this organisation, unpaid volunteers are treated like any other members of the team. We are invited to normal management meetings and we are asked about our opinions. We have the sense that our views count when managers make decisions" (Participant D)

From these experiences, it appears that the acclaimed concept of human resources are the most important assets (Bowen, Newenham-Kahindi and Herremans, 2010) in the organisation as the concept takes its full meaning in the voluntary sectors where leaders appear to practice what they preach. The organisations rely strongly on the totality of their human resources and believe in paid staff and volunteers. To maintain the quality of these human assets the leader attempts to increase their capacity of action by drawing on the diverse experience that both paid and unpaid volunteers bring to the organisation. There is the realization that people who come to work despite lower pay or unpaid work in the voluntary sector have special motivation, expertise and compassion that could be utilized in line with Shield et al.'s (2016) work. The CEO of the target organisation supported this line of argument when he explained that:

"I invite my volunteers to team meetings because they represent a tremendous source of ideas that help me make decisions and define strategy. I can say that most of the strategies I implement in this organisation are informed by the volunteers and the clients themselves who are also invited to some close meetings and consultation exercises. I don't make decisions without the input of my army of volunteers" (CEO of TFO).

Leaders draw on the expertise of the volunteers in their bank of trainers. Volunteers come from various boards of life and bring skills that leaders can use to provide regular training and development programmes. These resources can be discovered if working relationships in the voluntary sector are collegial and enable people to table what they can contribute. The volunteers believed that their consistent involvement in training other volunteers and public campaigns on some refugee issues was attractive and motivating. Two unpaid volunteers explained their motivation for offering their expertise to the organisation:

"I delivered training for many client organisations and coached other charity staff because I'm passionate about the work with migrants but also because I was asked 
The views of the managers and the volunteers demonstrate that voluntary sector action transcends the conflict model which is exemplified in the use of authority and power (Uhl-Bien et al. 2007). Leadership in the refugee-assisting organisation in this research is bottom-up and invite ideas from the people and deploy these ideas for compassionate action. This diverges from the private and public sectors which are target driven, power-orientated and top-down (Miller et al., 2012). Funding is a critical issue across the not-for-profit sector generally. The target organisation was no different. The CEO described critical areas of funding shortages which hampered efforts to develop important projects such adult refugee enhancement, domestic violence among the refugee communities which may go unreported and dealt with due to cultural stigmas, homelessness, etc. (Ógáin, Lumley \& Pritchard, 2012).

Since the financial recession 2007/2008, funding has become a majestic issue for the charitable organisation. However, often when only doom and gloom could be seen on the horizon, the voluntary sector leader has been able to rally his troops to go on the funding offensive. Again, collective approaches have delivered results. One of the three paid volunteers interviewed showed how this was possible:

"Once the manager came and said that we could all lose our jobs but more importantly hundreds of clients we assist are risk getting no assistance due to the funding cuts from the council and the government. But then, a volunteer suggested that we hold a fundraising gala (despite the lack of funds for this). She went around all her contacts to assess what they could donate to make the event happen. A company donated their venue, some donated refreshments and others printed invites and banners, etc. The volunteer got her contacts to persuade some authorities including the MPs and councillors to attend. The event was so successful that we raised over $£ 12,000$, enough for a part-time project worker to continue the counselling and advice service" (Participant B).

Emphasis on fundraising is a major strategic focus for the voluntary organisation (Steinerowski \& Steinerowska-Streb, 2012; Steinmann et al., 2015) including organisation studied. The organisation strives to have its image permanently in the public arenas with the understanding 
that this is a sine qua non-condition for effective operation (Shield, Drolet \& Valenzuela, 2016; Katz \& Page, 2010). The organisation is mainly dependent on grants from various sources and as such funding leadership is critical to survival. Many voluntary sector companies have disappeared (Shield, Drolet \& Valenzuela, 2016) due to the lack of leadership funding attributes among its managers. As a result of leadership effectiveness, organisations receive positive comments from politicians and the public. Fiona Mactaggart Labour Member of Parliament (MP) acknowledged that the voluntary organisation studied was resilient due to its leadership approach, pointing out that:

"This is an active organisation that plays a vital role in the lives of refugees in the town. These guys [managers and volunteers at the refugee agency] are funding champions", Fiona Mactaggart, MP, 2010).

Funding in the voluntary sector, in general, remains a big issue (Shield, Drolet \& Valenzuela, 2016; Steinerowski \& Steinerowska-Streb, 2012; Steinmann et al., 2015). Small voluntary organisations rely on grants from statutory agencies and trusts as well as street and door-to-door fundraising. In addition to under-staffing, voluntary organisations devote effort and time to fundraising. As TFO's CEO acknowledged:

"Fundraising is hard and time-consuming. It requires lengthy form filling and research to support the bid. Without a leader that pushes things very few voluntary organisations, particularly those of small size like ours, won't survive" (CEO of TFO).

Despite good intentions, hard work and strategies, there are challenges that leaders of small voluntary sector organisations face. Such a vulnerable position explains why despite praises from politicians, the public and service users, the CEO puts humbly that voluntary sector leaders are set to remain "permanent beggars". She does not see this as a negative attribute but a key quality in funding leadership in the voluntary sector. However, Ridley-Duff (2007) argues that, in doing so, voluntary sector leadership rejects the traditional discourse of power in the private enterprise (Uhl-Bien, 2007) and adopts other approaches to tackle social exclusion" by doing more with less.

\subsubsection{Resilience of Small Voluntary Sector's Social Solidarity}

Constraints of the external environment do not affect only the private or public sectors. The data from our interviews with the leadership and staff at the target refugee-assisting agency 
demonstrates that voluntary sector organisations could be more vulnerable to environmental fluctuations. This line of argument is tenable given the earlier point made that the voluntary sector is dependents on outside sources to funding and operations. The metaphor of "permanent beggars" used by the agency's CEO is enlightening; it supports the perspective about voluntary sector vulnerability to environmental change. This means that voluntary sector leaders face complex situations that require the application of complexity leadership. Several changes have taken place at the target organisation, but the agency has managed them through creativity and innovation. The CEO explained that:

"The organisation is resilient and remains at the forefront of innovation and expertise in refugee issues. Leaders are like tireless marathon runners whose attention is fixated on the final goal: ensuring clients' welfare through the running of meaningful activities that help rebuild lives" (CEO of TFO).

Creative action plays an important part in realising most of TFO's action plan. The resilience that voluntary sector organisation shows in this approach can be characterised as complexity leadership. As Uhl-Bien, Marion and McKelvey (2007:298) argue, complexity leadership is a leadership paradigm that focuses on enabling the learning, creative, and adaptive capacity of complex adaptive systems. TFO works closely with numerous refugee groups in the local community and social network to extend their service provision.

All staff interviewed, both leaders and volunteers, saw new asylum legislation as complicated, making it difficult to advise clients. Legislation on the entitlement to benefits, education and housing are continuously evolving. The legislation makes it impossible for refugees to apply to study at university and some higher education courses. No regulation bans them from applying to universities but the rule on fees restricts such moves. Refugees are liable for higher fees in universities. This means a refugee applying to university needs to pay standard fees in excess of $£ 9000$ per year, which is difficult given their precarious situation, i.e. being destitute with no relatives in the UK (Sardinha, 2009). The CEO and the three-paid staff were unanimous in appraising the situation:

"Voluntary sector leaders have to interpret these complex legislations in order to explain to their client the constraints faced in the attempt to assist them. Sometimes it feels like we are not willing to help them find education or jobs. The volunteers often have to bring the CEO to meeting with clients so that the clients could hear from the top about the realities we face in helping them" (Participant A). 
This is just the tip of the iceberg when it comes to asylum regulation. In reality, there are far more regulations restricting refugees' freedom. For instance, under the 1999 Asylum legislation, some claimants are detained while others are dispersed throughout the country. New arrivals wait a long time for a decision and can neither enter education nor work. The legislation makes refugee agencies' work harder as part of their fightback (Eikenberg, 2009). The Terrorism Act 2000 (and its multiple recent amendments) have compounded the issues faced by voluntary sector agencies. Many new arrivals now face detention if they are undocumented or arrive from a number of countries that are on the government 'watch list', e.g. Syria, Libya, Yemen, etc. In these cases, refugee organisations deploy additional resources to cater for refugees' welfare whilst they are detained (Clutterbuck \& Dearlove, 1996).

Additionally, the voluntary sector often leases buildings from local authorities. Initially when TFO moved in the premises were ideal. It was their own premises where they could develop activities to meet the needs of the client in confidence. However, with the increasing numbers of refugees, the location became small. Moving to larger premises would suggest more financial resources for rent and service charges. This is unaffordable to many organisations, particularly smaller ones. Funders are reluctant to fund the cost of premises. The difficulty is reflected in the views of the CEO who argues that:

"It's not easy to get money for core funding much of which doesn't cater for critical management and administrative expenses. As a leader, you have to be resilient to cope with these complexities. And you need dedicated volunteers to assist you" (CEO of TFO).

Staffing is equally an issue because there are few paid workers. Volunteers are often dedicated and highly motivated individuals. They give their time freely. However, because volunteers come for a limited amount of time, and may leave anytime:

"It's challenging for leadership to ensure access to a pool of volunteers to maintain service levels" (CEO, 2015).

Partner agencies perceive workers differently depending on whether they are volunteers or paid staff. In many instances, volunteers do practical jobs on-site, e.g. advisers, befrienders, childcare workers, kitchen helpers, cleaners, administrative workers, etc.

\subsubsection{Social Solidarity, Small Voluntary Organisations on Refugee Lives}


Social embeddedness shows how immigrants, in many cases lacking in social and financial capital (Craig, 2015; Kloosterman, 2010). The only place to come to experience or re-live social human experience is the local refugee-assisting voluntary group. Similar conclusions were reached by Shield, Drolet \& Valenzuela (2016). Refugees appreciate the warm welcome by staff, which is enabled by a sensitive leader. Some refugees idealised the refugee organisation, arguing that:

"This is a familiar place'. The group provides reassurances. The tea, coffee and friendship they show make us feel at home. The services provided touch with our hearts and lives" (Group interview Clients 1, 2 and 3, 4).

The words of the client respondents demonstrate that compassion stretches beyond food and drinks. The clients valued the warm human approach to service provision, with staff who understand the psychological needs of their clients and connect with them. It is purported that compassionate leadership drives the voluntary sector provision (Miller et al., 2012) and the data from our study appear to point to additional core elements as friendly, 'familial' and caring atmosphere. This way of welcoming and nurturing the refugees fosters citizenship development as refugees then start to internalize British values of volunteering and compassionate giving (see Ógáin, Lumley \& Pritchard, 2012). The unpaid volunteers explained why they came to volunteer:

"We were all former clients of this organisation. We were touched by the way they looked after us and we decided to come to give something back by helping other newcomers to settle" (Group interview Participants D, E, F).

Most refugees are destitute, particularly since the late 1990s when a number of benefits and welfare entitlements were withdrawn for a large number of refugees in the UK. The clients would come to support groups for advice, welfare information and assistance. The system is complicated, and the clients do not always understand it (Bloch, 2004). Advisers in the voluntary sector advise on rights and entitlements and help complete relevant forms. Staff and volunteers speak to welfare agencies on clients' behalf because many do not speak English competently. Customers appreciate this significant assistance; an interviewee from Burundi told the researchers that:

"Staff take time to fill these forms and phone to sort out problems which the refugee couldn't do" (Client 4). 
Small voluntary organisations are at the heart of the community, 'representing parental' (Client 11) figures in the eyes of more than half of the users interviewed, similar to the perspectives taken by De Hoogh et al. (2005). The allocation of funds by some public bodies attests such importance although these funds are limited and may be restricted. Clients 1, 3, 4, 11 and 15 argued that:

“Activities like the Job Club, Mum's Club and English conversation classes are really good help because they create for us a sense of community and networks. We can feel part of a group and not be alone" (Group interview, Clients 1, 3, 4, 11 and 15)

The refugee agency's community action delights the clients and fulfils a social and citizenship development mission. The voluntary sector provides integrated services that meet clients' psychological and social needs, thus contributing to the equality agenda. As Tomlinson \& Schwabenland (2010) argue "moral and business rationales are reconciled through re-inscribing utilitarian arguments within an organisational commitment to social justice”. Similarly, Ógáin, Lumley \& Pritchard (2012) argue that voluntary sector agencies make a significant impact on society through such provision.

The unemployment rate among refugees is largely above the national average in the UK. Nationally, the unemployment rate is $5.3 \%$ (IDS Statistics, 2006) but this is around $70 \%$ (Bloch, 2004) among refugees; these figures for migrant workers have been confirmed by several other studies in recent years, e.g. Rienzo (2016). Many clients come to the voluntary groups for assistance with job search, including advice on job vacancies, completing job application forms, $\mathrm{CV}$. Clients found the services both culturally-sensitive and culturally-inviting. In fact, as client 13 argued:

"The English language classes are beneficial because they accommodated difference, but they also help to understand British culture. We mix with different nationalities and men and women; this we were not used to in our countries of origin, but it is very important for our life in the UK" (Client 13).

TFO was perceived as a place of social and economic opportunities and citizenship construction in line with the concept of mix embeddedness (Kloosterman and Rath, 2001). These opportunities are foundations refugees can exploit to rebuild broken lives, seek employment or 
start a business to pursue a living. Shield, Drolet \& Valenzuela (2016) formulated similar conclusions, confirming small voluntary sector groups as strategic partners in the construction of inclusive societies. Most of the participants described the most challenges facing refugees in rebuilding their lives. They point to that many of the refugees are highly educated, employed in professional jobs or owned their own businesses in their home countries which they left behind. They point to the role of the government and VROs in resettlement and rehabilitation through training and support mechanism that enables them to pursue paid or self-employment. Without these social integrations and community integration will be impossible.

\section{Discussion, Conclusion and Implications}

The last 10 years have witnessed the highest levels of refugees since World War II, nearly 22.5 million people (United Nation, UN, 2018). As a result, VROs have become an integral part of the society, running schemes geared at integrating refugees in host societies. There are many refugee agencies, including the British Refugee Council and Refugee Action, which make significant media headlines. But there are also less lauded community voluntary organisations and self-help groups, whose work has been under-researched or published. These agencies have emerged over the years to fill a void and provide much needed humanitarian assistance. On arrival to host countries, refugees need to rebuild their lives, find shelter, paid employment or self-employment.

As stated earlier, this article contributes to a better understanding that the small VROs play in refugee integration in the UK society (Phillimore \& Goodson, 2010; Mayblin \& James, 2018), particularly, within the context of the global refugee and humanitarian crisis. Our findings reveal the role that the VROs play in refugee integration and the development of citizenship behaviour of refugees. We find cases of exemplary leadership in actions of VROs and social solidarity exhibited in times of need through creative actions. It revealed the mixed embeddedness that enable refugees to pursue social, economic and citizenship construction. As revealed, SVA harness compassionate action, which is not for profit, and leadership filled with humanistic and familial values.

Our study shows how the small voluntary sector organisation studied (TFO) developed strategies to help integrate refugees who are affected by the migration crisis. Despite political and financial difficulties, small voluntary organisations, such as TFO, effectively assist vulnerable refugees by doing more with less, with compassion. Our research corroborates 
Moskovich's (2015: 635) view that "NGOs are a sophisticated counterculture, with activists who know how to operate concurrently with and against official authorities. This duality is important for social cohesion and citizenship. Our research question has therefore been answered. Particularly in the refugee-assisting sector, organisations face tremendous challenges with immigration and asylum legislation.

Some of the challenges that face the VROs include difficulties in fundraising, acquiring premises and sourcing staffing. Despite the difficulties, small voluntary organisations develop visionary and imaginative initiatives whose compassionate characteristics overcome practical challenges and resist commercialization (Nickel \& Eikenberry, 2009). Their role becomes more important in helping refugees to integrate into society, seek employment or start a business as self-employed. Participants explained that compassion was not a source of organisational incapacity but learning to work with hardship enabled the organisation to fathom creative leadership in the refugee integration field.

\subsection{Social Implications of VROs embedded in Social Solidarity}

Scholten et al., (2017) studies provide evidence that European countries have faced increasing levels of asylum applications over the years 2015 and 2016. Therefore, the presence of humanitarian migrants requires countries to look beyond the immigration and reception policies per se but also to focus on integration. The local response by smaller organisations is significant. In 2015/16, there were 2,976 visits to Asylum Welcome's main office; 2,321 food parcels were handed out; 1,029 clients - including 88 unaccompanied young asylum seekers and refugees received help (Mayblin \& James, 2017). VROs compliment the role of government and therefore has become an integral element to refugees' integration and settlement in their host communities.

The tangible and intangible resources that the agencies provide is vital to the overall integrated system and are important for achieving inclusive employment and entrepreneurship (OECD, $2016 \&$ 2017). Compassionate voluntary sector action drives the voluntary organisation and makes a difference to lives at the same time as developing citizenship behaviour in the newcomers. They also support rebuilding refugees' lives by enabling them access resources that will allow them to pursue paid employment or self-employment in the form of entrepreneurship. This account to why many migrant's own shops in many European cities and urban centres. This finding is supported by Shield, Drolet \& Valenzuela (2016). Clients appreciate the human side of the organisation, highlighting qualities such as friendship, welcoming, helpfulness, and sense of belonging and hope they are led to experience. Social aspects are essentials and must be 
embedded in refugee integration policy and competency frameworks to help rebuild refugees' confidence and self-esteem. The clients were interviewed in different locations, but their views converge in appreciating the compassion and service quality, which gives them confidence in the new society. This implies interconnections between social solidarity, integration and inclusion.

\subsection{Policy Implications}

This research has significant policy implications. The economic and political changes that have taken place globally in recent years has left much government weak and incapable to providing all the social and economic responsibility, leaving voluntary agencies (the third-sector) as important stakeholders than ever (Home Office; 2006; Scholten et al. 2017; Scholten \& Van Breugel, 2017). At its simplest level, policy-makers should adhere to a principle of 'do no harm' to small voluntary organisations as their role is critical to social integration and value creation. The work of the target organisation in this study shows that refugee integration ought to remain an on-going endeavour (Mayblin \& James, 2017). With evidence of the tremendous achievement and expertise of the VS in refugee integration, thus fashioning citizenship in the newcomers, it is opportune to advocate a more strategic partnership between the public sector and voluntary sector in the form of increased funding and outsourcing initiatives to the latter. In fact, Papademetriou, Benton \& Banulescu-Bogdan (2017:1) argue that "as the pressures have started to abate, policymakers have started to concentrate their efforts on anticipating the next crisis". However, though this is a good initiative, the welfare of those already in the host country's care should be a priority as we have actual numbers and needs to cater for.

\subsection{Research Implication and Limitations}

The evidence suggests that asylum seekers can become destitute at all stages in their asylum journey, including while in the asylum system, and after being granted leave to remain, and that those who are in receipt of asylum support are living in poverty and have needs which exceed state provision (Mayblin \& James, 2017). This has led researchers and policy-makers to examine the integration of asylum seekers and refugees in many contexts (labour market integration (Madsen, 2016 Trygstad, 2016), welfare, societies and family relations (Olwig, 2011), integration governance (Scholten \& Van Breugel, 2017; Strang \& Ager, 2010), yet gaps remain regarding the role of RTSOs. This formed the focus and contribution of our study as we reveal the role of SVAs. Indeed, SVAs promote community cohesion which benefits the wider 
community as part of their broader strategic agenda. By responding to the needs of all communities, including newly arrived communities, it is possible to achieve benefit for the whole society. As our findings revealed, SVAs complement government policies in the labour market, educational, sociocultural, housing, healthcare integration of asylum seekers and refugees.

Finally, we acknowledge that the research approach adopted has some limitations. A key limitation of this study as with all qualitative studies is its limited scope and number of interviewees. As Gartner (2007:619) stated, "the narrative approach recognises that a story is never the whole story since any story is embedded in a context". Despite its limitations, the study design provides the foundation for future studies. We propose that future research should widen the scope to cover many scopes by studying multiple VROs. Given the fact that the large and small VROs focus on the same objective (social integration), examining and comparing institutional change across small and large organisations will provide a fruitful avenue for future research. It would be worthwhile to examine the difference in the leadership solidarity among the different sizes of the VROs.

\section{Notes \& Further Reading}

1. Adirondack Sandy (1990), “Just about managing”. London: London Voluntary Service Council. United Kingdom

2. Dhudwar, A. (2004), “Towards a Refugee Employment Strategy”, ILJ, 286.

3. Eurostat (2018), "Asylum statistics" https://ec.europa.eu/eurostat/statistics-explained/index.php/Asylum_statistics

4. Handy Charles (1976), “Understanding Organisations”. Penguin, London, UK

5. Hacky-Polay, D. (2016), "Reframing migrant integration: Redefining citizenship and nationhood in Europe”. Kibworth: The Book Guild. London, United Kingdom

6. United Nations (2018), "Refugees": http://www.un.org/en/sections/issues-depth/refugees/

\section{References}

Atfield, G., Brahmbhatt, K. and O'Toole, T. (2007), "Refugees' experiences of integration." London, Refugee Council/University of Birmingham. United Kingdom

Atkinson, A.B., Backus, P.G., Micklewright, J., Pharoah, C. and Schnepf, S.V. (2012), "Charitable giving for overseas development: UK trends over a quarter century" Journal of Royal Statistical Society, Vol. 175 No.1, pp. 167-190

Bevelander, P. (2016), "Integrating refugees into labor markets. IZA World of Labor: 269 
Bevelander, P., \& Pendakur, R. (2014), “The labour market integration of refugee and family reunion immigrants": A comparison of outcomes in Canada and Sweden. Journal of Ethnic and Migration Studies, Vol. 40 No.5, pp. 689-709.

Bloch, A. (2004), "Making it work: refugee employment in the UK". London: Institute of Public Policy Research. The United Kingdom.

Bowen, F., Newenham-Kahindi, A. \& Irene, H. (2010), "When Suits Meet Roots: The Antecedents and Consequences of Community Engagement Strategy". Journal of Business Ethics, Vol. 95 No. 2, pp. 297-318.

Bull, M. (2008), "Challenging tensions: critical, theoretical and empirical perspectives on social enterprise". International Journal of Entrepreneurial Behavior \& Research, Vol. 14 No. 5, pp. 268-275, https://doi.org/10.1108/13552550810897641

Clutterbuck D., Dearlove, D. (1996), "The charity as a business: managing in the public sector, learning from the private sector". London: DSC. United Kingdom

Craig, C. (2015), "Migration and integration: A local and experiential perspective", Institute for Research into Superdiversity. IRiS Working Paper Series, No. 7/2014. Birmingham: UK

Crockett, D.R. (2013), “Immigrant entrepreneurs' selectivity: host market distance and opportunity". Journal of Enterprising Communities: People and Places in the Global Economy, Vol. 7, pp. 196-212

Dahles, H, Verduyn, J.K. and Wakkee, I.A.M. (2010), "Introduction to a special issue on soci(et)al entrepreneurship". Journal of Enterprising Communities: People and Places in the Global Economy, Vol. 4 No. 1, pp. 5-12

Dahlstedt, I., \& Bevelander, P. (2010), “General versus vocational education and employment integration of immigrants in Sweden". Journal of Immigrant \& Refugee Studies, Vol. 8 No. 2, pp. 158-192.

De Hoogh, A.H.B., den Hartog, D.N., Koopman, P.L., Thierry, H., van den Berg, P.T., van der Weide, J.G., and Wilderom, C.P.M. (2005), "Leader motives, charismatic leadership, and subordinates' work attitude in the profit and voluntary sector". Leadership Quarterly, Vol. 16 No.1, pp.17-38.

De Hoogh, A.H.B., Annebel et al., (2005), "Leader motives, charismatic leadership, and subordinates' work attitude in the profit and voluntary sector". The Leadership Quarterly, Vol. 16 No.1, pp. 17-38.

Doyle, L. (2014), "28 days later: experiences of new refugees in the UK”, London Refugee Council, https://www.refugeecouncil.org.uk/assets/0003/1769/28 days later.pdf Accessed 11/04/2018

Eikenberry, M.A. (2009), "Refusing the Market - A Democratic Discourse for Voluntary and Non-profit Organizations". Non-profit and Voluntary Sector Quarterly, Vol. 38 No. 4, pp. 582-596.

Eurofound (2016), "Approaches to the labour market integration of refugees and asylum seekers." Publications Office of the European Union, Luxembourg.

European Migration Network (2016), "Report on Asylum and Migration". Brussels, Belgium.

Evans, A.J. (2012), "Ethnic enterprise governance: a public choice analysis of Liverpool's Chinatown". Journal of Enterprising Communities: People and Places in the Global Economy, Vol. 6, pp. 28-38.

Fitzpatrick, S., G. Bramley, J. Blenkinsopp, S. Johnsen, M. Littlewood, G. Netto, F. Sosenko, and B. Watts. (2015), "Destitution in the UK": An Interim Report. York: Joseph Rowntree Foundation.

Galbraith, C.S. (2010), "Handbook of Qualitative Research Methods in Entrepreneurship". Journal of Enterprising Communities: People and Places in the Global Economy, Vol. 4 No.1, pp.109-111, https://doi.org/10.1108/17506201011029537 
García, M.-C.D. and Welter, F. (2011), "Gender identities and practices: interpreting women entrepreneurs' narratives”. International Small Business Journal, Vol. 31 No. 4, pp. 384-404.

Griffiths, D., Sigona, N. and Zetter, R. (2005), "Refugee community organisations and dispersal: networks, resources and social capital.” Bristol, Policy Press. UK

Hack-Polay, D. (2008), "Missed opportunity: the underutilisation of forced migrants in British labour market". Working Papers, CIBS, London, United Kingdom.

Hack-Polay, D. (2007), "Compassionate leadership in voluntary organizations and the integration of forced migrants". Paper presented at 7ème Rencontres ESS Rennes University, France. Accessed: 20/03/2018 http://repository.upenn.edu/cgi/viewcontent.cgi?article $=1001 \&$ context $=$ spp papers

Home Office (2006), "A new model for national refugee integration services in England, London, Home Office.

IDS Statistics (2006), "Employment and unemployment": latest figures released in June 2006. http://www.incomesdata.co.uk/statistics/statempl.htm, accessed 04/07/06.

Igwe, P.A., Icha-Ituma, A. and Madichie, N.O. (2018). An Evaluation of CSR and Social Value Practices Among UK Commercial and Social Enterprises. Entrepreneurial Business and Economics Review, Vol. 6 No. 1, pp. 37-52. https://doi.org/10.15678/EBER.2018.060102

Igwe, P.A., Madichie, N.O. and Newbery, R. (2018), "Determinants of livelihood choices and artisanal entrepreneurship in Nigeria", International Journal of Entrepreneurial Behavior \& Research, https://doi.org/10.1108/IJEBR-02-2018-0102 [Early Cite]

Igwe, P.A., Newbery, R., Amoncar, N., White, G. R.T., Madichie, N.O. (2018), "Keeping it in the family: exploring Igbo ethnic entrepreneurial behaviour in Nigeria". International Journal of Entrepreneurial Behavior \& Research, https://doi.org/10.1108/IJEBR-12-2017-0492 [Early Cite]

Jacobsen, K., \& Fratzke, S. (2016), "Building livelihood opportunities for refugee populations: lessons from past practice". Migration Policy Institute.

Kloosterman, R.C. (2010), "Matching opportunities with resources: a framework for analysing (migrant) entrepreneurship from a mixed embeddedness perspective", Entrepreneurship and Regional Development, Vol. 22 No. 1, pp. 25-4

Kloosterman, R.C. and Rath, J. (2001), "Immigrant entrepreneurs in advanced economies: Mixed embeddedness further explored". Journal of Ethnic and Migration Studies, Vol. 27, pp. 189-201.

Knight, J. (2015), "The evolving motivations of ethnic entrepreneurs". Journal of Enterprising Communities: People and Places in the Global Economy, Vol. 9, pp. 114-131.

Konle-Seidl, R. (2018), "Integration of Refugees in Austria, Germany and Sweden: Comparative Analysis, Brussels: European Parliament, http://www.europarl.europa.eu/RegData/etudes/STUD/2018/614200/IPOL_STU(2018

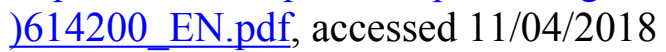

Konle-Seidl, R. and Bolits, G. (2016), "Labour market integration of refugees: Strategies and good practices" European Parliament, Brussels

Kouzes, M.J. and Posner Z.B. (1993), "Credibility: how leaders gain it and lose it: Why people demand it”. Jossey Bass. New York, USA.

Kyoung-Ho, S. (2014), "Korean entrepreneurs in Kansas City metropolitan area: an immigrant community under ethnic local and global intersection". Journal of Enterprising Communities, Vol. 8, pp. 287-299. 
Lin, K-M. (1986), "Psychopathology and Social Disruption in Refugee". In C. Williams \& J. Westermeyer (Eds.) Refugee mental health in resettlement countries. Hemisphere Publishing, Washington, USA.

Lundborg, P., \& Skedinger, P. (2016), "Employer attitudes towards refugee immigrants: Findings from a Swedish survey". International Labour Review, Vol. 155 No.2, pp. 315-337

Lukes, M. and Ute, S. (2012), "Non-profit leaders and for-profit entrepreneurs: similar people with different motivation". Ceskoslovenska Psychologie Praha, Vol. 56 No.1, pp. 4155

Lupton, D.R. (2015), "Toxic Charity: How Churches and Charities hurt those they help". Poverty, Inc. HarperCollins Publishers, New York, USA

Madsen, P. K. (2016), "Labour market integration of asylum seekers and refugees". Denmark. European Commission. Directorate- General for Employment, Social Affairs and Inclusion. Accessed: 03/4/2018 www.ec.europa.eu/social/BlobServlet?docId/15909\&langId/en

Mayblin, L. \& James, P. (2017). "Asylum and refugee support: civil society filling the gaps?" University of Warwick, Coventry, CV4 7AL, UK https://naccom.org.uk/wpcontent/uploads/2017/02/civil-society-filling-the-gaps-october-2017.pdf

Mayblin, L. \& James, P. (2018), “Asylum and refugee support in the UK: civil society filling the gaps"? Journal of Ethnic and Migration Studies, [Early Cite] https://doi.org/10.1080/1369183X.2018.1466695

McKeever, E., Jack, S. and Anderson, A.R. (2015), "Embedded entrepreneurship in the creative re-construction of place". Journal of Business Venturing, Vol. 30, pp. 50-65.

Miller L., Toyah, et al. (2012), "Venturing for Others with Heart and Head: How Compassion Encourages Social Entrepreneurship". Academy of Management Review, Vol. 37 No. 4, pp. 616-640

Molm, L.D., Collett, J., Schaefer, L. and David R. (2007), "Building Solidarity through Generalized Exchange": A Theory of Reciprocity", American Journal of Sociology Vol. 113 No.1, pp. 205-242. https://doi.org/10.1086/517900

Moskovich Y., Binhas, A. (2015), "NGOs helping migrants: an Israeli case study of

Counterculture". International Journal of Sociology and Social Policy, Vol. 35 No. 9/10, pp. 635-648 https://doi.org/10.1108/IJSSP-11-2014-0109

Munkejord, M.C. (2017), "Immigrant entrepreneurship contextualised: Becoming a female migrant entrepreneur in rural Norway". Journal of Enterprising Communities: People and Places in the Global Economy, Vol. 11 No. 2, pp. 258-276

Ógáin N.E., Lumley, T. and Pritchard D. (2012), "Making an impact - impact measurement among charities and social enterprises in the UK'. New Philanthropy Capital, London, United Kingdom.

Okolie, C. U., Igwe, P. A. and Elom, E. N. (2018), "Improving graduate outcomes for Technical Colleges in Nigeria", Australian Journal of Career Development, [...] pp. 1-20 DOI:10.1177/1038416218772189 Accepted 30 April 2018. [In press]

Olwig, K. F. (2011), “Integration': Migrants and Refugees between Scandinavian Welfare Societies and Family Relations". Journal of Ethnic and Migration Studies, Vol. 37 No.2, pp. 179-196

Organisation for Economic Co-operation and Development (2016) "Inclusive entrepreneurship in Europe -an OECD-European commission project", available at: www.oecd.org/cfe/leed/inclusive-entrepreneurship.htm (Accessed 19 May 2017).

Organisation for Economic Co-operation and Development (2017) The Missing Entrepreneurs: Policies for Inclusive Entrepreneurship, OECD, Paris, France, available at: http://dx.doi.org/10.1787/9789264283602-en (Accessed 10 May 2018) 
Page, M. (1998), "Compassionate leadership: a question of gender? The experiences of women managers in refugee organizations". Evelyn Oldfield Unit. London, UK

Papademetriou, D.G., Benton, M. and Banelescu-Bogdan, N. (2017), "Rebuilding after crisis: embedding refugee integration in migrant migration management systems". Migration Policy Institute, Washington DC, USA

Phillips, D. (2006). "Moving toward integration: the housing of asylum seekers and refugees in Britain." Housing Studies, Vol. 21 No.4, pp. 539-553.

Phillimore, J. and Goodson, L. (2010), "Failing to Adapt: Institutional Barriers to RCOs Engagement in Transformation of Social Welfare." Social Policy and Society, Vol. 9 No. 2, pp. 181-192.

Price, J. (2016) Meeting the Challenge: Voluntary Sector Services for Destitute Migrant Children and Families, COMPAS: Oxford University.

https://www.compas.ox.ac.uk/2016/meeting-the-challenge-voluntary-sector-services-fordestitute-migrant-childrenand-families/

Rafique Z. and Khoo, S.L. (2018), "Role of community-based organisations (CBOs) in promoting citizen participation: A survey study of local government institutions of Punjab, Pakistan". International Journal of Sociology and Social Policy, Vol. 38 No. 3/4, pp. 242-258, https://doi.org/10.1108/IJSSP-02-2017-0008

Reeves, S., Peller, J., Goldman, J. and Kitto, S. (2013), "Ethnography in qualitative educational research". AMEE Guide No. 80, Medical Teacher, Vol. 35 No.8, pp. e1365-e1379,

Refugee Action (2015), "Facts about refugees" https://www.refugee-action.org.uk/about/facts-about-refugees/, Accessed 11/04/2018

Refugee Council (2002), "Credit to the nation: a study of refugees in the United_Kingdom. Refugee Council, London, UK.

Ratten, V. and Dana, L.-P. (2017), “Gendered perspective of indigenous entrepreneurship". Small Enterprise Research, Vol. 10 No.1, pp. 62-72.

Rienzo, C. (2016), "Characteristics and Outcomes of Migrants in the UK Labour Market." Migration Observatory, January 2016, Briefing, COMPAS, University of Oxford

Rousseau, J.J. (1913), "Social Contract \& Discourses". E. P. Dutton \& Co. New York, USA.

Ruiz, I. and Vargas-Silva, C. (2017), Differences in labour market outcomes between natives, refugees and other migrants in the UK, Oxford: Centre on Migration, Policy and Society (COMPAS).

Sardinha J. (2009), "Immigrant Associations, Integration and Identity: Angolan, Brazilian and Eastern European Communities in Portugal". Amsterdam: Amsterdam University Press.

Scholten, P., Baggerman, F., Dellouche, L., Kampen, V., Wolf, J. \& Ypma, R. (2017), "Policy Innovation in Refugees Integration? A comparative analysis of innovative policy strategies toward refugee integration in Europe". Erasmus University Rotterdam.

Scholten, P. and Van Breugel, I. (2017), "The mainstreaming of integration governance”. Routledge, London, UK.

Shield J., Drolet, J., Valenzuela K. (2016), "Immigrant Settlement and Integration Services and the Role of Non-profit Providers: A Cross-national Perspective on Trends, Issues and Evidence," RCIS Working Paper No. 2016/1.

http://www.ryerson.ca/content/dam/rcis/documents/RCIS\%20WP\%202016 01\%20Sh ields\%20et\%20al\%20final.pdf, accessed 02/10/2016.

Spencer, S.[ed.] (2006). "Refugees and other new migrants a review of the evidence on successful approaches to integration." Oxford, COMPASS. UK 
Steinmann, B., Dörr, S.L., Schultheiss, O.C, Maie,r G.W. (2015), "Implicit motives and leadership performance revisited: What constitutes the leadership motive pattern"? Motivation and Emotion, Vol. 39 No. 2, pp. 167-174.

Steinerowski, Artur \& Steinerowska-Streb, Izabella (2012), "Can social enterprise contribute to creating sustainable rural communities? Using the lens of structuration theory to analyse the emergence of rural social enterprise." Local Economy, Vol. 27 No. 2, pp. $167-182$

Stephens, S. (2013), "Building and entrepreneurial network: the experiences of immigrant entrepreneurs". Journal of Enterprising Communities: People and Places in the Global Economy, Vol. 7, pp. 233-244

Strang, A., \& Ager, A. (2010), "Refugee integration: Emerging trends and remaining agendas". Journal of Refugee Studies, Vol. 23 No.4, pp. 589-607.

The Scottish Government (2017). "New Scots: Integrating Refugees in Scotland's Communities 2014 - 2017”. Final Report. ISBN: 978-1-78652-696-0 Published by The Scottish Government, March 2017 file:///C:/Users/user/Downloads/00515713.pdf

Turkina, E. and Thai, M.T.T. (2013), "Social capital, networks, trust and immigrant entrepreneurship: a cross-country analysis". Journal of Enterprising Communities: People and Places in the Global Economy, Vol. 7, pp. 108-124

Trygstad, S. (2016), "Labour market integration of asylum seekers and refugees". European Commission, Norway. Brussels

Uhl-Bien, M., Marion R., McKelvey, B. (2007), "Complexity Leadership Theory: Shifting leadership from the industrial age to the knowledge era". The Leadership Quarterly, Vol. 18 No. 4, pp. 298-318.

Valenta, M. \& Thorshaug, K. (2012), “Asylum seekers' perspective on work and proof of identity: the Norwegian experience'. Refugee Survey Quarterly, 31(2), pp. 76-97

Van Heelsum, A. (2017), "Aspirations and frustrations: experiences of recent refugees in the Netherlands". Ethnic and Racial Studies, Vol. 40 No. 13, pp. 2137-2150.

Vathi, Z. and King, R. (2013), "Have you got the British? narratives of migration and settlement amongst Albanian-origin immigrants in London". Ethnic and Racial Studies, Vol. 36 No. 11, pp. 1829-1848.

Warrell, M. (2017), “Compassionate Leadership: A Mindful call to lead from both head and heart", Forbes, https://www.forbes.com/sites/margiewarrell/2017/05/20/compassionateleadership/\#2411a25a5df9, accessed 26/10/2017

Watson, T.J. (2012), "Making organisational ethnography". Journal of Organizational Ethnography, Vol. 1 No. 1, pp.15-22, https://doi.org/10.1108/20466741211220615 


\section{Reviewer: 1}

\section{Comments:}

- The topic is interesting and relevant but the build-up is not strong and thus I am left with the feeling so what is new.

Thank you very much for the feedback. We feel we have now addressed your concern. We have made changes to the abstract, introduction, the context and the discussions and conclusion. We have strengthened the theoretical context and literature with the addition of new 25 articles and publications.

1. The abstract is not informative.

The abstract has been further developed as your advised. Thank you

2. The introduction does not justify why this study is needed.

The introduction has been revised and new context and justification as to the need for the study added. Thank you very much

3. The literature review is mostly outdated.

The literature has been revised and new 25 articles added, many of them articles 2010 2018. Thank you for your observation.

The new additions include:

Mayblin, L. \& James, P. (2017). The Scottish Government (2017). Eurofound (2016),

Scholten, P., Baggerman, F., Dellouche, L., Kampen, V., Wolf, J. \& Ypma, R. (2017)

Bevelander, P., \& Pendakur, R. (2014). Bevelander, P. (2016). Dahlstedt, I., \& Bevelander, P. (2010). European Migration Network (2016). Jacobsen, K., \& Fratzke, S. (2016).

Konle-Seidl, R. and Bolits, G. (2016), Lundborg, P., \& Skedinger, P. (2016).

Okolie, C. U., Igwe, P. A. and Elom, E. N. (2018), Madsen, P. K. (2016).

Olwig, K. F. (2011). Scholten, P. and Van Breugel, I. (2017).

Atfield, G., Brahmbhatt, K. and O'Toole, T. (2007). Griffiths, D., Sigona, N. and Zetter, R.

(2005). Phillips, D. (2006). Spencer, S.[ed.] (2006)

Home Office (2006). Strang, A., \& Ager, A. (2010).

Trygstad, S. (2016).

Valenta, M. \& Thorshaug, K. (2012).'

van Heelsum, A. (2017).

4. The study looks more like pigeonholing as the authors already have what they want to find.

This concern has been addressed with the revision of the context, issues, justification, need and the discussion to provide a wider context and scope. 
5. The selection of respondents was also not clearly explained.

Thank you for the advice. We have revised to include as: Participants were chosen through purposeful sampling procedure (Igwe, Newbery, Nihar, White and Madichie, 2018; Okolie, Igwe and Elom, 2018) aimed at selecting key members of the staff who had many years of working experience in the case study agency.

6. The discussion has centred on Refugee Integration and I do not see anything surprising emerging.

In response, we have developed a wider context - refugees, asylum and migration context. Thank you for your observation.

7. More detail is required regarding discussion and implications.

Again, Thank you for the feedback. We have now expanded the section $5.1-5.3$ to summarize and articulate what we have done and how our study relates to previous studies. In addition to providing the major contributions and limitations.

\section{References check for completeness and format.}

These has now been addressed. In addition, we have also cited:

Crockett, D.R. (2013), "Immigrant entrepreneurs' selectivity: host market distance and opportunity". Journal of Enterprising Communities: People and Places in the Global Economy, Vol. 7, pp. 196-212

Dahles, H, Verduyn, J.K. and Wakkee, I.A.M. (2010), "Introduction to a special issue on soci(et)al entrepreneurship". Journal of Enterprising Communities: People and Places in the Global Economy, Vol. 4 No. 1, pp. 5-12

Evans, A.J. (2012), "Ethnic enterprise governance: a public choice analysis of Liverpool's Chinatown". Journal of Enterprising Communities: People and Places in the Global Economy, Vol. 6, pp. 28-38.

Galbraith, C.S. (2010), "Handbook of Qualitative Research Methods in Entrepreneurship", Journal of Enterprising Communities: People and Places in the Global Economy, Vol. 4 No.1, pp.109-111

Knight, J. (2015), "The evolving motivations of ethnic entrepreneurs". Journal of Enterprising Communities: People and Places in the Global Economy, Vol. 9, pp. 114-131

Munkejord, M.C. (2017), "Immigrant entrepreneurship contextualised: Becoming a female migrant entrepreneur in rural Norway". Journal of Enterprising Communities: People and Places in the Global Economy, Vol. 11 No. 2, pp. 258-276

Stephens, S. (2013), "Building and entrepreneurial network: the experiences of immigrant entrepreneurs". Journal of Enterprising Communities: People and Places in the Global Economy, Vol. 7, pp. 233-244

\section{Reviewer: 2}

Recommendation: Minor Revision

Comments: Lengthen 5.1-5.3.

Thank you very much for your feedback. We have revised and extended the Section 5.1 5.3 and developed our conclusion and implications. 
Additional Questions:

$<b>1$. Originality: $</ b>$ Does the paper contain new and significant information adequate to justify publication?: Yes, it is on an interesting area of study being refugee entrepreneurship and has recent 2018 references.

Thank you very much. We have also added new 25 articles to strengthen our literature.

$<b>2$. Relationship to Literature: $</ b>$ Does the paper demonstrate an adequate understanding of the relevant literature in the field and cite an appropriate range of literature sources? Is any significant work ignored?: Yes, recent references are included but please reference more feom this journal if at all possible.

Also, sections 5-5.3 have references so I don't know about that.

Thank you very much. This concern has been addressed. We have made sure all the cited work has been provided at the end of reference list.

$<b>3$. Methodology: </b > Is the paper's argument built on an appropriate base of theory, concepts, or other ideas? Has the research or equivalent intellectual work on which the paper is based been well designed? Are the methods employed appropriate?: Ok.

Thank you very much for your comments.

$<b>4$. Results: $</ b>$ Are results presented clearly and analysed appropriately? Do the conclusions adequately tie together the other elements of the paper?: Ok but a lot of quotes.

Thank you very much

$<b>5$. Implications for research, practice and/or society: $</ b>$ Does the paper identify clearly any implications for research, practice and/or society? Does the paper bridge the gap between theory and practice? How can the research be used in practice (economic and commercial impact), in teaching, to influence public policy, in research (contributing to the body of knowledge)? What is the impact upon society (influencing public attitudes, affecting quality of life)? Are these implications consistent with the findings and conclusions of the paper?: Sections 5.3 should be longer and in more detail.

Thank you very much. These issues have now been addressed. We have extended section $5.1-5.3$ and summarized our study and how it relates to the overarching research.

$<b>6$. Quality of Communication: $</ b>$ Does the paper clearly express its case, measured 
against the technical language of the field and the expected knowledge of the journal's readership? Has attention been paid to the clarity of expression and readability, such as sentence structure, jargon use, acronyms, etc.: Ok

Thank you very much. 